\title{
Political Economy of Berau Forest Carbon Program Implementation
}

\author{
Yuniarti $^{1}$, Tendy $^{2}$, Budiman $^{3}$,Cathas Teguh Prakoso ${ }^{4}$ \\ \{yuniarti2306@yahoo.com\} \\ Universitas Mulawarman ${ }^{1,2,3,4}$
}

\begin{abstract}
Berau Forest Carbon Program (BFCP) is one of the first demonstration actions of Reducing Emissions from Deforestation and Forest Degradation Plus (REDD+) in Indonesia. The goal of the program is to develop a sustainable natural resource management base-development model while reducing emissions and environmental impact. This article explains BFCP implementation in the point of view interest and political economy theories. In its implementation, the program involved a cooperation amongs actors. In the perspective of political economy, these actors interacted in the social and institutional processes, bargaining for their interests. Although, there are several interest are bargained, the remained concern was that environmental issues, whether local or global, were security problem which should be done together. There are some patterns of behavior shown in the interaction between actors. Firstly, the Indonesia Government and Berau Government, whose main interest is to conserve and protect the environment in the same time as encouraging local economy. Secondly, local society, who is empowered in order to be primary actor in the conservancy program. Thirdly, TNC, the non-governmental organization, which act as a program designer for people empowerment. And, fourthly, US Government through USAID as the donatur. US Government also utilize the program to shift its responsibilities to protect the global environment to Indonesia in the framework of deb for nature swap based on its TFCA between the two government.
\end{abstract}

Keywords: BFCP, Political Economy, Interest.

\section{Introduction}

International Berau Forest Carbon Program (BFCP) is a pilot project of the implementation Reduction of Emissions from Deforestation and Forest Degradation Plus (REDD+) in Kabupaten Berau, Kalimantan Timur, Indonesia. It was initiated at the Conference of Parties 13 (CoP 13) UNFCCC, Bali 2007, later known as Bali Action Plan (BAP). BAP became a negotiation roadmap to carry out global warming post-Protocol Kyoto in 2012. Clean Development Mechanism (CDM) which is one of Protocol Kyoto's Strategies enables developing countries to participate and join the program to eliminate emission through conservation, sustainable management of forests and enhancement of forest carbon stocks.

Within the REDD+ program, the Government of Indonesia designed implementation stages by conducting demonstration action in several areas. One of the chosen areas is Kabupaten Berau, Province Kalimantan Timur. The action is SIGAP-REDD+ (Aksi Inspiratif 
Warga untuk Perubahan dalam REDD+). By means of parties facilitating the process, such as Government of Indonesia, Governments of Kalimantan Timur and Berau, and The Nature Conservancy (TNC), Berau Forest Carbon Program (BFCP) was created. BFCP aims to incarnate Berau as a local development model based on sustainable low carbon natural resources management [1].

The succeed of the program implementation made it became a pilot project area of REDD+ to the world in the year of 2010. This achievement invited some foreign elites to observe the program directly. They are Minister of Development and Economic Cooperation of Germany, and the United States of America (USA) Ambassador for Indonesia, Minister of Environment and Climate Change of Norway.

US Government responded it by initiating partnership cooperation via Tropical Forest Conservation Act (TFCA) Scheme Kalimantan Siklus I. The cooperation involved both government and non-governmental organizations, TNC and WWF Indonesia. Memorandum of Understanding was signed 29 September 2011 which stated that US Government serve Rp. 40 billion grant and debt for nature swap scheme for US\$ 28,5 for tropical forest conservation program in Indonesia, specially Kalimantan. TFCA had a major role in supporting BFCP from the demonstation action toward full implementation. It was proved by the signing of the second agreement in 2014, dan the third one in 2015 to 2030 [2].

Although BFCP was claimed as efectual program, it was a complicated program. It needed a lot of effort to combine and harmonize many of interest colided within it. The interest of political elites and that of economic elits, domestically and extraneously. In political economy perspective, there are several interest bargained in social and institutional processes, such as market and private sector related to forest industies, local societies whose live depended on forest, national and international non-governmental organizations which concern with forest conservation, local, national and foreign governments which have focus on balancing the economic demands and forest resources in sustainable development process.

Gilpin explined that political economy is reciprocal and dynamics interaction of the pursuit of wealth and the pursuite of power. Although both are concerned with the effects of the relationship of economics and politics, the formulation here stresses the organization of theses activities in modern era. In the other words, Markets certainly constitute a means to achieve and exercise power, and the state can be and is used to obtained wealth. State and market interact to influence the distribution of power and wealth in international relations [3]. Thus, states seek to protect themselves and limits the cost to themselves and their citizens. The struggle among groups and states over distribution of benefits and cost has become a major feature of international relations [3]. In political economy, state has central role in decission making process, followed by the nonstate actors, such as individual and corporations. However, sometimes, these nonstate actors's interests exactly become influential preferences in the decission making process in bargaining process. Therefore, it is not impossible when the regulations benefits the private corporations rather than national interest.

Morgenthau described that national interest is the most important element of political realism. It was defined as all of state efforts to pursuite power [4]. Similarly, Gilpin deepened the power concept as military, economic, or psychological power between states [5]

National interest is vital element of a state included survival of the nation-state, freedom and territory integrity, military, and wealth [6]. In the other hand, national interest is relative concept. It means, it has no general definition widely accepted. Therefore, understanding the role or the meaning of national interest might be perceived or interpretate in a different orientation. As Ken Kiyono explained that relations amongs states is dynamics and change over time according time and space [7]. 
Relations between interest and state also explained by Ravenhill in the realism and international economy. Basically, realism has no reference toward political economy. Nevertheless, in global political economy, the idea of realism simply illustrate states' behavior in achieving their national interests in bargaining process both bilaterally or multilaterally in many activities as international trade, foreign direct investment, or the other transnasional activities [8]. He also noted that each state in its interaction towards the others always promote their national interests. The negotiation and bargain of these interests would be resulted with agreement.

In environment or forest management, there is a clash interest between exploitation and restoration since there are different needs of forest of three components. These are local society, corporation related to forest industries, the state who has the solely power on environment regulations. Geller argued how the environment issue arrised as the impact of the transformation and dynamic of global political economy [9]. Conversely, in turn, environment degradation affect the economy and security later on. Geller added that environment degradation lead to economic stagnation, political disorder, and internal (social) conflict.

Environment transformation, degradation or natural disaster will result in food, water, and energy crisis. Once these come into emergence, internal conflict appears as a result. The government is demanded to cope with these problem (fulfilling people basic needs) otherwise the conflict worsened. Government failure lead to wider conflict and violence in the society level and government itself. It is widely believed by the expert that climate change and environment issues have full impact to state security so as become national threat. In the other words, climate change closely related to seciruty study.

\section{Methodology}

This article is aiming at explaining the implementation of BFCP in perspective political economy and concept of interest. This is qualitative study using primary and secondary data. The data collected by literature review. The purpose of the review is designing framework of thinking and theoritical argument to explaining the question of the research. Then the data analysed by interactive model of Miles and Huberman. The model started from data collection, data condentation, data display to conclusions drawing.

\section{Result and Discussion}

\subsection{Berau Forest Carbon Program}

The implementation of BFCP is under regulation of Permenhut No. P.20/Menhut-II/2012, about Forest Carbon. This regulation replaces three of the previous regulations on REDD+, which were Permenhut No.P.68/Menhut-II/2008 of The Implementation of Demonstration Activities of Reduction of Emissions and Deforestation and Forest Degradation; Permenhut No.P.30/Menhut-II/2009 of The Procedures of Reduction of Emissions and Deforestation and Forest Degradation (REDD), and Permenhut No.P.36/Menhut-II/2009 of The Procedures of Business Licensing of Absorbent Utilization and/or Carbon Stock on Production Forest and Protected Forest.

The seriousness of Berau Government in implementing this national program was proved by the decision of issuing the Decree through Surat Keputusan (SK) Bupati No. 313 Tahun 2008 of the Establishment of Working Group REDD Berau Regency, SK Bupati No. 766 Tahun 2010, 30 November 2010 of the Appointment of Forestry Service as District Project Management Unit (DPMU), and SK Bupati No. 114 Tahun 2011 of the Establishment of Directing Council of BFCP. 
Hence, this program was implemented with the strategy of integrated low carbon development and strengthening the enabling condition including planning, management, involvement of stakeholders and good financing management, and also investment in area such as community development, wood management in rights of forest cultivation (Hak Pengusahaan Hutan/HPH), palm oil and protected forest, and also in the area of industrial forest and mining. BFCP developed its strategy by allocating full technical assistance and supporting governmental agents, the owners of forest management rights, communities, which is considered to be the main actors in determining the impact of field usage in Berau [10].

This program developed the pilot project of emission reduction from deforestation and forest degradation, and that of the increase of carbon stock through the activity of sustainable forest management, forest conservation, restoration of ecosystem, and forest rehabilitation. This program known as REDD+. This program took into action within some phases, starting scoping phase, developing phase, and pilot phase. After the third phase, pilot phase, program continued the next phase, which is the full force implementation.

Some achievements during the pilot phase included: (1) the availability of layout of which is the main foundation of license issuing in Berau, (2) the forming of Regional Medium-Term Development Plans (/RPJMD) and Spatial Plans (/RTRW), which preceded by the Strategic Environmental Studies (/KHLS), (3) two of business permit holder for utilization of timber forest products (/IUPHHK-HA) which certified with FCS and 12 IUPHHK-HA which certified with Management of Sustainable Production Forest (/PHPL), (4) the forming of Village Medium-Term Development Plans (/RJPM) in several villages in approach of SIGAP, (5) 5 villages gaining Village Forest Management Rights, which are Kampung Merbau, Long Ayap, Punan Segah, Biatan Ilir, dan Dumaring, and (6) the forming of GIS Forum in Berau [9]. The implementation of this pilot program is claimed to be successful policymakers and stakeholders involved within.

In order to create low emission local development BFCP developed two strategies. Firstly, strategy of strengthening the enabling condition, and secondly, site-based strategy.

a. Strategy of strengthening the enabling condition was implemented cross-sectorally.

The purpose is strengthening the enabling condition so the causes deforestation and land degradation can be minimalized. This strategy covered the improvement of spatial planning and land use, improvement of management of forest sector, involvement of policy makers and stakeholders, improvement of prosperity and involvement of community, development of sustainable funding management and incentive distribution, and development of monitored, reported, and diversified low emission calculation system.

b. Site-based strategy was implemented at the management unit level.

It is aiming to develop the model of emissions reduction in all types of forest management. This strategy includes improvement of production forest management, improvement of protected forest management, improvement of palm field management, and improvement of mangrove management.

One of the significant debates in implementing REDD+ is about how to ensure that community is not to be disadvantaged in this program. This debate came from the thought of some negatives impact of the program that might occur, such like the disappearance of access and control of communities to forest which also considered as a threat for their living. This also means that the benefits of the program only enjoyed by just a few parties.

To avoid such as condition, TNC has designed community empowerment program, where community can be the integral part in process of planning, execution, and monitoring of REDD+. Local communities have also be involved in decision making process which based on clear information and without coercion. Community involvement can be defined into two 
parts. First, encouraging the participation of communities in the climate change mitigation in site level. This performed with strengthening community vision which relevant with the management of natural resources, inventorize local wisdom and potential of land using into land using management plan for today and the future. The potential and land using method was casted into natural resources plan corresponded to village plan. This commitment was interpretated in the agreement to mitigate the climate change in each villages. Two, ensuring that communities become the essential part in strategic decision making in REDD+ program. This means that community and the representatives of community have to be involved in discussion and decision making in REDD+ at any levels. This circle of discussions will play part as a learning class/room for communities to voice up their aspirations to decision makers $[1]$.

After 5 (five) years of preparations covering scoping phase, developing phase, and pilot phase, by year 2016 the BFCP was officially taking full force of implementation. Entering the phase of full implementation, the Regency of Berau was no longer holding the authority of forest management. But even so, the government has pledge to preserve its commitment. This commitment was based on the interest of its local communities in approach of the local community's empowerment. Through BFCP, Berau local communities are involved in management and preservation of forest sustainability.

Not only to ensure the rights of Berau local communities, this program was also considered to be able to give more benefits economically. These considerations also encouraged the emergence of an agreement by Directing Council of BFCP together with partner representatives in 31 May 2017, to continue BFCP dan term of Green Kaltim Program until 2030. In this program implementation, Berau achieves funding supports from United States, based on Tropical Forest Conservation Act / TFCA. This funding mechanism is a debt swap mechanism of Indonesia to US, known as debt-for-nature swap, which facilitates by TNC and WWF.

\subsection{Interest Bargaining in $B F C P$}

BFCP was born from the mutual initiation of several parties, such as Government of Berau Regency, Government of East Kalimantan Province, NGOs, donor agency (United States). This pictures the collaborations of actors from many levels with one ideal objective, which is to form the pilot program of emission reduction, which has been the significant issue of developed countries. This collaboration is dynamic with the formal involvement of Berau local communities in the management of Berau Forest.

For Indonesia, BFCP is not only about the commitment to global efforts in saving the earth, but it also a form of serious concern based on the awareness of the importance of the meaning of forest for ecological, economy, social, and humanity. The ignorance of human to these functions simply will create the threat for mankind todays or in future. Forest in Indonesia have facing heavy pressure, due to the uncontrolled granting of forest management/exploitation permits to private, which made the economic function dominate the consideration of forest management. Meanwhile, the considerations of ecology and social function ignored.

Depart from this condition, the interest of Indonesia in this program is practically ideal. Most of forests in Indonesia belong to public. And for that, there has been a significant interest to form an effective management model in building a network between stakeholders, and to evoke the political interest which walks harmoniously from all involving parties.

With abundant resources of forest, the initiatives and ideas of forest conservations seem to require numbers of money. To answer this, United States came with a help. US\$ 28.5 million disbursed for Indonesia as a grant to support the efforts of NGOs and local university to 
preserve the tropical forest in Kalimantan, with additional US\$ 500 million used in efforts to fight climate change, mitigate the impact of forest damages, preservation of biodiversity, and also beneficial for millions of Indonesian people who depend their living on forest sectors [11].

But as a receiving country, it seems that Indonesia's interest in this program is far more than just a pledge of commitment to environment. What seems to be the extension of Indonesia's noble interest from this program is that, not only Indonesia is helped to realize its commitment to environment, but also Indonesia is helped to reduce its foreign debt burden to United States. This is a big relieve for Indonesian economy.

Both situations are good. But something needs to be noted. In this debt swap scheme, Indonesia is stepping into the negative trend of foreign aid. The involvement of foreign party like United States allows the emergence of structural hierarchy, which is potential to erode the sovereignty of Indonesia to its own forest management. This structure of hierarchy is enabled mostly because of the common pattern of global environmental regime, such like United Nations Frameworks Convention on Climate Change (UNFCCC), which says that the efforts of saving the earth will run in equality based cooperation but in different responsibility and capacity [12].

In this point of view, BFCP doesn't automatically put Indonesia in the top of structure. United States as a funding party through TFCA, supported with skill of TNC will play most significant part, compare to Indonesia who holds only the ownership and monitoring functions. For example, TNC plays role in designing, developing, and forming the strategy regarding the efforts of reducing emission as a result of deforestation and forest degradation. TNC also develops the model of BFCP management, which includes the role of Directing Council, BFCP Working Group. Another important role played by TNC includes building partnership nationally and internationally [1].

In other side, it seems that United States also projected its interest more than just a single commitment to environment. It is easy to see that power politics displayed clearly by United States in order to achieve its goals regarding environmental regime. As country which concern the most about protecting and preserving forest and biodiversity by reducing the emissions, United States in fact doesn't seem to be willing to associate with environmental regime such like REDD in Kyoto Protocol. But even so, United States always claim that the country has a long history in supporting conservation efforts in many parts in the world, and always willing to cooperate to protect the environment for the sake of humanity generations to generations [1].

To realize this, United Stated has its own way to contribute to environment. Avoiding a tight bind of environmental regime, United Stated created TCFA program. TCFA was created under the fact that this country contributes about $1 / 5$ of global glass house emission. But as a non-tropical country with no forest, United Stated pushed to seek another alternative by engaging with developing countries blessed with high carbon absorbent capacity of tropical forest. United States' strategy by engaging developing country like Indonesia is seemed mostly as national strategic agenda than a global commitment.

REDD+ Program in Berau, in other point of view, often addressed as a threat to national sovereignty. This program is more like the strategy of United States to avoid its noble responsibility in efforts to reduce emissions, which is believed to be part of responsibility of industrialization in developed countries. With its financial power, United Stated tends to put this responsibility to Indonesia. This suspicion came with the fact that the number of funding allocated in REDD+ is worth far below, compared to actual worth of the forest area worked in this program [13]. Meanwhile upon receiving the aid in REDD+, based on agreement in 
UNFCCC, Indonesia has to agree not to use forest for industrial needs. In other word Indonesia has to close it forestry industry.

Even though REDD+ in Indonesia face many resistance, but government seems to keep the optimistic point of view to this program. At least there are two reasons construct this point of view. (1) REDD+ is believed to be the best solution to fight deforestation and forest degradation. Through this program the level of deforestation and forest degradation decreased from 1.7 million ha in 2004/06 to 0.5 million ha in 2009/11. (2) Foreign funding contributes positively for Indonesian economic interest. For example, Indonesia enjoys the possibility of aid worth US\$ 5.6 million each year from REDD+ scheme across Indonesia [13].

\section{Conclusion}

In the perspective polical economy and concept of interest, the dynamics of bargaining process in the interaction involved parties with their interests involved. These actors are Berau Government, local societies, NGOs such as TNC and WWF, and the last is US Government. First, Berau Government has the solely power to regulate the implementation of sustainable development model. It also has power to alocate and distribute forest resources into the market. However, the reality shows that it has very limited capital resources. Therefore, in BFCP, Berau Government enabled itself to fulfill the responsibility to reduce emissions hand in hand with the opportunity to utilize international funding in the development and to empower local societies in forest management. Second, in BFCP strategy designed by TNC, local societies became the primary focus. It is simply because local societis and communities' life heavily depended on the forest. The strategy should benefits them. This societies could have been marginalized if their natural rights to utilize the forest were shifted certain groups, or the incentive given were unfair. Hence, TNC enforce their participation from the initial process of planning, decission making, and implementing. People empowerment is a compulsory mission because their interest means their survival. And, it is the goal of the development itself. Local wisdom was the heart of the strategy.

Third, as a facilitator agent, TNC's interest is conserve the forest. The program was directed to ensuring the local and regional development corresponded to environment-based. It was a complicated task for TNC since it had to put its activities according to the regulation, and in the hand, practical needs could not be compromised to local authority's interest. Fourth, US Govenrment's interest was fulfillment its global responsibility to reduce emission through REDD shceme. To run this responsibility, US provided forest conservation fund in TFCA Program. Concept of debt for nature swap was implemented in BFCP to divert its obligation to Indonesia. It seemed that all parties gained their interests since BFCP implementation as a pilot project was claimed effectual.

\section{References}

[1] H. et. al. Hartanto, SIGAP-REDD+: Aksi Inspiratif Warga untuk Perubahan REDD+. Jakarta: The Nature Conservancy, 2014.

[2] M. Ghofar, "Program Karbon Hutan Berau Diperpanjang Hingga 2030." .

[3] G. Robert, The Political Economy of International Relations. New Jersey: Princeton Unversity Press, 1987.

[4] M. J. Hans, Politics Among Nations. New York: Knopf, 1948.

[5] G. Robert, Global Political Economy: Understanding the International Economic Order. Princeton: Princeton University Press, 2001.

[6] J. C. Plano, R. Olton, and P. A. (Penerjemah) Bardin, Kamus Hubungan Internasional. 
Bandung: CV Rajawali, 1982.

[7] K. Ken, A Study on the Concept of the National Interest of Hans J. Morgentahu: As the Standard of American Foreign Policy. Nagasaki: Nagasaki University, 1966.

[8] R. John, Global Political Economy, 4th ed. Oxford: University Press, 2014.

[9] G. J. Chad, "Climate Change and Environment Security: Bringing the Realism Back," SSRN J., 2010

[10] Indonesia REDD, "Hutan Berau, Kalimantan Timur." .

[11] US Embassy, "AS dan Indonesia Memberikan Hibah untuk Meningkatkan Kelestarian Hutan dan Memerangi Perubahan Iklim." .

[12] C. et al. Anne, "Land-based Investment and Green Development in Indonesia: Lessons from Berau district, East Kalimantan," 2015.

[13] S. T. E. Yakob, "Ironi REDD+ di Indonesia: Cerita dari Kalimantan Tengah," Harian IndoPROGRESS, 2014. 